\title{
Erosive wear of a surface coated hydroturbine steel
}

\author{
AKHILESH K CHAUHAN, D B GOEL* and S PRAKASH \\ Department of Metallurgical and Materials Engineering, Indian Institute of Technology Roorkee, \\ Roorkee 247 667, India
}

MS received 21 February 2008

\begin{abstract}
In the present investigation, stellite-6, $\mathrm{Cr}_{3} \mathrm{C}_{2}-\mathrm{NiCr}$ and $\mathrm{WC}-\mathrm{Co}-\mathrm{Cr}$ coatings were deposited by $\mathrm{D}-$ Gun on a hot rolled $21 \mathrm{Cr}-4 \mathrm{Ni}-\mathrm{N}$ steel meant for fabrication of hydro turbine underwater parts. The coatings have been characterized for microstructure, porosity, microhardness and crystalline nature. The erosion experiments were carried out using an air jet erosion test rig at a velocity of $120 \mathrm{~ms}^{-1}$ and impingement angles of $30^{\circ}$ and $90^{\circ}$. Silicon carbide particles of size ranging between 500 and $700 \mu \mathrm{m}$ were used as erodent. Scanning electron microscopy (SEM) technique was used to analyse the nature and mechanism of erosion. Erosion behaviour is observed to be influenced largely by the nature and extent of porosity in the surface coatings.
\end{abstract}

Keywords. D-Gun sprayed coating; porosity; stellite-6; $\mathrm{Cr}_{3} \mathrm{C}_{2}-\mathrm{NiCr}$; erosion.

\section{Introduction}

The loss of material caused by the impingement of tiny solid particles, which have a high velocity and impact on the material surface at defined angles, is called erosive wear (Guo et al 1995). Erosion is a serious problem in many engineering systems, including steam and hydro turbines, pipelines and valves used in slurry transportation of matter, and fluidized bed combustion systems (Kosel 1992). Coatings of wide variety of materials are commonly applied for many purposes, especially to improve tribological performance; that include the enhancement of mechanical properties, visual appearance or corrosion resistance and optical properties. It has been reported that the thermal spray is a technique that produces a wide range of coatings for various applications (Herman and Sampath 1996). Erosion tests on coatings have been widely reported (Barbezat et al 1993; Takeda et al 1993; Wang 1993; Shipway and Hutchings 1995; Hearley et al 1999; Wang and Lee 2000; Mishra et al 2006; Sidhu et al 2007). The mechanisms of coating damage in such tests depend on the coating material and its thickness, the properties of the interface, the substrate material and the test conditions (Shipway and Hutchings 1995).

Among the commercially available thermal spray coating techniques, detonation spray and high velocity oxy fuel spray are the best choices to get hard, dense and consequently wear resistant coatings (Barbezat et al 1993; Wang 1993; Semenov and Cetegen 2002). Thermally

*Author for correspondence (dbgmtfmt@iitr.ernet.in) sprayed coatings of thickness, 200-400 $\mu \mathrm{m}$, offer an effective and economic method of conferring wear resistance without compromising other attributes of the component. Detonation Gun (D-Gun) spraying has been shown to be one of the best methods for depositing coatings because of the higher velocities and lower temperatures experienced by the powder particles (Fagoaga et al 1998; Wang et al 2000).

In an earlier paper (Chauhan et al 2008), it has been reported that hot rolled 21-4-N austenitic steel possesses excellent erosion resistance in comparison to $13 \mathrm{Cr}-4 \mathrm{Ni}$ steel (CA6NM), which finds wide application in hydro turbine underwater parts. In this work, attempts have been made to investigate the erosion behaviour of $\mathrm{D}-\mathrm{Gun}$ sprayed stellite- $6, \mathrm{Cr}_{3} \mathrm{C}_{2}-\mathrm{NiCr}$ and $\mathrm{WC}-\mathrm{Co}-\mathrm{Cr}$ coatings on hot rolled 21-4-N steel substrate. The analysis of eroded surfaces as well as coatings has been done using scanning electron microscope (SEM).

\section{Experimental}

\subsection{Substrate material}

The substrate material selected for the study was a nitronic steel (termed as 21-4-N steel), which was procured from M/s Star Wire (India) Ltd. Ballabhgarh (India) in the form of hot rolled bars of $40 \times 40 \mathrm{~mm}$ cross section. The chemical composition of the substrate material was (wt $\%$ ): $0.56 \mathrm{C}-9.9 \mathrm{Mn}-23.42 \mathrm{Cr}-4 \cdot 28 \mathrm{Ni}-0.38 \mathrm{~N}-$ $0 \cdot 25 \mathrm{Si}$-balance $\mathrm{Fe}$. The specimens measuring $40 \times 40 \times$ $10 \mathrm{~mm}$ were cut from the bars. The specimens were polished and grit blasted before subjecting to coating by D-Gun. 


\subsection{Surface coatings}

Three types of powders were used in the study, the chemical compositions of which are reported in table 1.

D-Gun spray equipment having horizontal orientation was used for coating of the samples at the worksite of M/s Sai Surfacing Co. Hyderabad (India). The D-Gun spraying process parameters are given in table 2 .

\subsection{Characterization of D-Gun sprayed coatings}

The microstructural features of the coated specimens were studied using optical microscope. Porosity of coatings was measured using a Zeiss Axiovert 200 MAT inverted optical microscope fitted with imaging software, Zeiss Axio Vision 4.1. Microhardness of the coatings was measured by Leitz's Hardness Tester Mini Load-2. Two hundred gram load was provided to the needle for penetration and the hardness value was determined based on the relation:

$$
\mathrm{HV}=189.03 \times 10^{3} \times\left(F / d^{2}\right),
$$

where $F$ is the load in gram, and $d$ the mean of the indentation diagonal length in $\mu \mathrm{m}$. For each hardness value, an average of ten measurements was taken. The XRD analysis was carried out using a Bruker AXS D-8 Advance Diffractometer with $\mathrm{CuK} \alpha$ radiation.

\subsection{Erosion testing}

Erosion tests were performed in a near sonic high velocity gas blast erosion rig facility developed as per standard followed by Wood and Wheeler (1999). The details of the design of test rig can be found in an earlier paper (Chauhan et al 2008). The erodents were accelerated down a $16 \mathrm{~mm}$ diameter stainless steel tube, $1 \mathrm{~m}$ in length, to

Table 1. Composition of coating powders.

\begin{tabular}{ll}
\hline Coating material & \multicolumn{1}{c}{ Composition (wt\%) } \\
\hline Stellite-6 & $30 \mathrm{Cr}-5 \mathrm{Fe}-6 \mathrm{~W}-1 \mathrm{C}-\mathrm{Co}(\mathrm{Bal})$ \\
$\mathrm{Cr}_{3} \mathrm{C}_{2}-\mathrm{NiCr}$ & $75 \mathrm{Cr}_{3} \mathrm{C}_{2}-25 \mathrm{NiCr}$ \\
$\mathrm{WC}-\mathrm{Co}-\mathrm{Cr}$ & $\mathrm{WC}-10 \mathrm{Co}-4 \mathrm{Cr}$ \\
\hline
\end{tabular}

Table 2. D-Gun process parameters.

\begin{tabular}{ll}
\hline Particle size & $35-45 \mu \mathrm{m}$ \\
Spray spot diameter & $25 \mathrm{~mm}$ \\
Spraying distance & $200 \mathrm{~mm}$ \\
Spraying atmosphere & Air \\
Thickness per shat & $5-6 \mu \mathrm{m}$ \\
Shots/s & 3 \\
Total coating thickness & $300 \mu \mathrm{m}$ \\
\hline
\end{tabular}

impact on the sample. Particle velocity of $120 \mathrm{~ms}^{-1}$ at a constant feed rate of $5 \mathrm{~g} \mathrm{~min}^{-1}$ was employed. The flux rate was kept below the level at which particle-particle interactions begin to significantly reduce the erosion rate (Shipway and Hutchings 1994). Dry compressed air was mixed with the particles, which were fed at a constant rate from a particle feeding hopper in the mixing chamber and then accelerated by passing the mixture through a tungsten carbide converging nozzle of $8 \mathrm{~mm}$ diameter. These accelerated particles impacted the specimen, which could be held at various angles with respect to the impacting particles using an adjustable sample holder.

The studies were performed on uncoated as well as coated specimens for the purpose of comparison. The erosion test conditions utilized in the present study are listed in table 3. A standard test procedure was employed for each erosion test. The samples were cleaned in acetone, dried, weighed to an accuracy of $1 \times 10^{-4} \mathrm{~g}$ using an electronic balance, eroded in the test rig for $10 \mathrm{~min}$ and then weighed again to determine weight loss. The ratio of this weight loss to the weight of the erodent particles causing the loss (i.e. testing time $\times$ particle feed rate) was then computed as the dimensionless incremental erosion rate. The erosion rate $(\mathrm{g} / \mathrm{g})$ versus erosion time ( $\mathrm{min})$ was plotted to compare the erosion rate of the substrate as well as the coatings. SEM study of eroded surfaces was conducted using LEO $435 \mathrm{VP}$ scanning electron microscope at an accelerating voltage of $15 \mathrm{kV}$.

\section{Results and discussion}

\subsection{Microstructures and XRD spectra}

Figure 1 shows the XRD spectra and optical micrograph of stellite- 6 coating. From the peaks in XRD spectra (figure 1a), it is observed that the stellite- 6 coating consists of $\mathrm{Cr}_{23} \mathrm{C}_{6}$ and $\mathrm{Co}$ ( $\gamma$ or $f c c$ ), of which chromium carbide $\left(\mathrm{Cr}_{23} \mathrm{C}_{6}\right)$ is the dominating hard phase. The microstructure of stellite as shown in figure $1 \mathrm{~b}$ consists of fine chromium carbides in the austenitic matrix of $\mathrm{Co}$. Some of the dark etching regions may also be due to porosity. Identical observation has been reported by Singh et al (2005)

Table 3. Erosion parameters

\begin{tabular}{lc}
\hline Erodent material & Silicon carbides \\
\hline Particle size $(\mu \mathrm{m})$ & $500-700$ \\
Particle velocity $\left(\mathrm{ms}^{-1}\right)$ & 120 \\
Air pressure $(\mathrm{kPa})$ & 196 \\
Impact angle $\left({ }^{\circ}\right)$ & 30 and 90 \\
Nozzle diameter $(\mathrm{mm})$ & 8 \\
Test interval $(\mathrm{min})$ & 10 \\
Working distance $(\mathrm{mm})$ & 10 \\
\hline
\end{tabular}


for plasma sprayed stellite-6 coating on Fe-based superalloy.

Figure 2 shows the XRD spectra and optical micrograph of the $\mathrm{Cr}_{3} \mathrm{C}_{2}-\mathrm{NiCr}$ coating. From the peaks in XRD spectra (figure 2a), it is observed that the $\mathrm{Cr}_{3} \mathrm{C}_{2}-\mathrm{NiCr}$ coating is made up of carbides and oxide phases, including $\mathrm{Cr}_{3} \mathrm{C}_{2}, \mathrm{Cr}_{3} \mathrm{Ni}_{2}$ and $\mathrm{Cr}_{2} \mathrm{O}_{3}$. In HVOF $\mathrm{Cr}_{3} \mathrm{C}_{2}-\mathrm{NiCr}$ coating, apart from $\mathrm{Cr}_{3} \mathrm{C}_{2}$ carbide particles, the carbides $\mathrm{Cr}_{7} \mathrm{C}_{3}$ and $\mathrm{Cr}_{23} \mathrm{C}_{6}$ might be also present according to the reported results through X-ray diffraction analyses (Ji et al 2006). It is likely that these carbides are formed through decarburization of $\mathrm{Cr}_{3} \mathrm{C}_{2}$. However, it is further pointed out that the presence of $\mathrm{Cr}_{7} \mathrm{C}_{3}$ and $\mathrm{Cr}_{23} \mathrm{C}_{6}$ in the as-sprayed $\mathrm{Cr}_{3} \mathrm{C}_{2}-$ $\mathrm{NiCr}$ coating cannot be proven solely by X-ray diffraction approach because their main diffraction peaks coincide with the lines referring to the $\mathrm{NiCr}$ and $\mathrm{Cr}_{3} \mathrm{C}_{2}$. As seen in figure $2 \mathrm{~b}$, the microstructure of $\mathrm{Cr}_{3} \mathrm{C}_{2}-\mathrm{NiCr}$ coating is characterized by bright phases as the binding matrix in which the dark/gray regions are carbides of type, $\mathrm{Cr}_{3} \mathrm{C}_{2}$ and/or chromium oxide $\left(\mathrm{Cr}_{2} \mathrm{O}_{3}\right)$. The very dark points observed in the binding matrix may be due to porosity. Similar observations have been reported by Wang et al (2000).
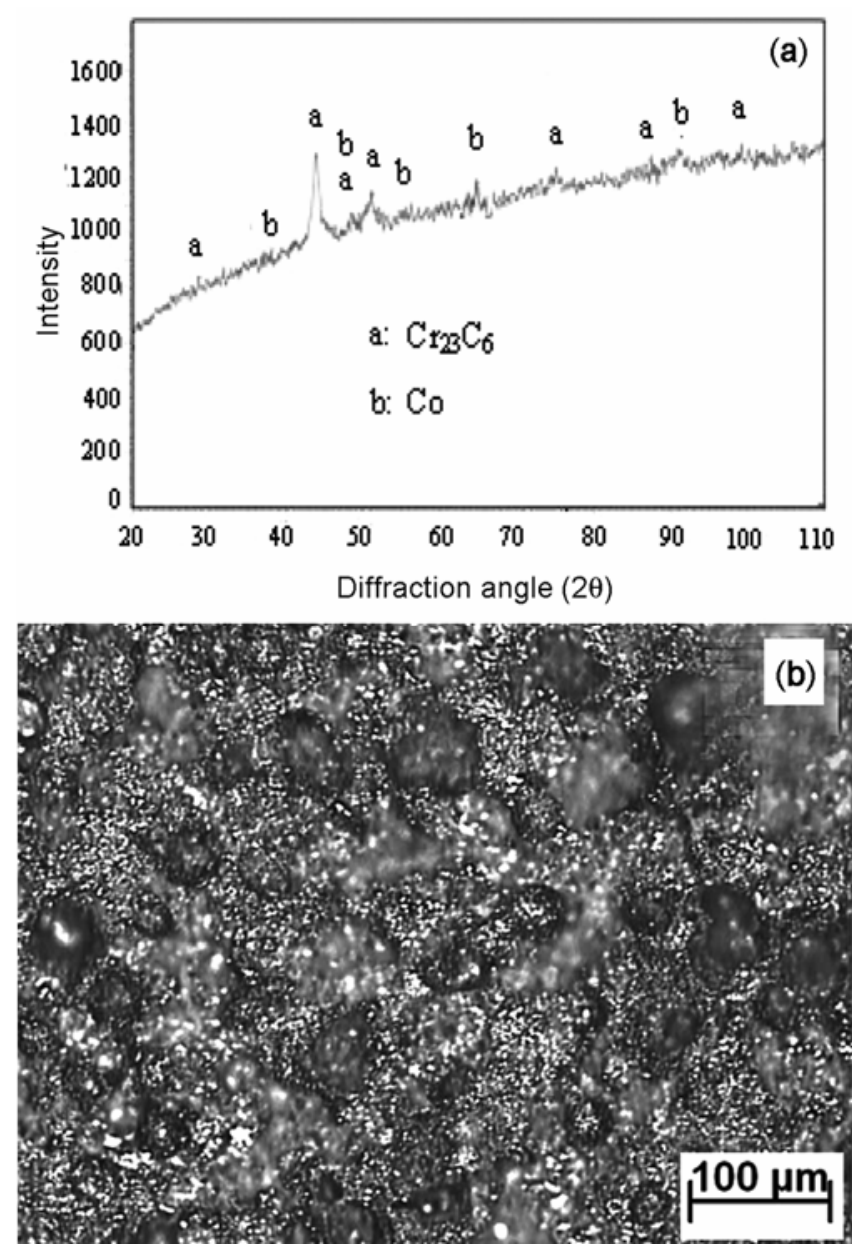

Figure 1. (a) XRD spectra and (b) optical micrograph of stellite- 6 coating.
Figure 3 shows the XRD spectra and optical micrograph of the $\mathrm{WC}-\mathrm{Co}-\mathrm{Cr}$ coating. From the peaks in XRD spectra (figure $3 \mathrm{a}$ ), it is observed that the $\mathrm{WC}-\mathrm{Co}-\mathrm{Cr}$ coating contains $\mathrm{Co}_{3} \mathrm{~W}_{3} \mathrm{C}, \mathrm{WC}, \mathrm{W}_{2} \mathrm{C}$ and $\mathrm{CrCo}$, of which $\mathrm{Co}_{3} \mathrm{~W}_{3} \mathrm{C}$ and $\mathrm{WC}$ are the major hard phases. The presence of $\mathrm{W}_{2} \mathrm{C}$ phase in this coating indicates the decarburization of WC during coating process. Chromium addition to WC-Co inhibits the decarburization of WC to metallic tungsten. Similar XRD peaks have also been reported by Sahraoui et al (2003) and Zhang et al (2007). As seen in figure $3 \mathrm{~b}$ the microstructure of $\mathrm{WC}-\mathrm{Co}-\mathrm{Cr}$ coating consists of carbides well distributed and bonded within the Co based binding matrix. Bright/gray areas indicate binding matrix in which $\mathrm{WC}$ is dissolved in solution. Dark particles of carbides are seen in blocks of bright etching binding matrix. Identical observations have been reported by Murthy et al (2001).

\subsection{Porosity and microhardness measurements}

The average porosity and microhardness of the D-Gun sprayed coatings are given in table 4 . The average poro-
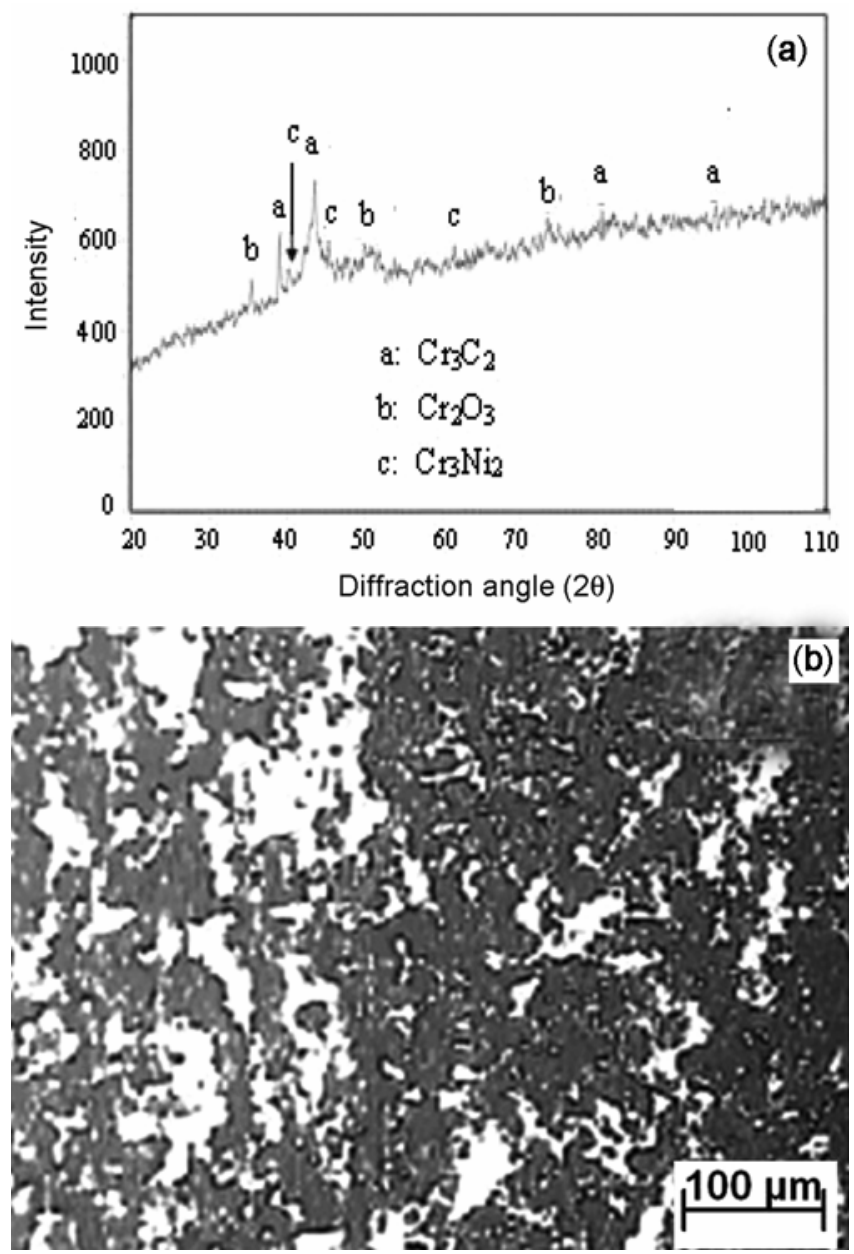

Figure 2. (a) XRD spectra and (b) optical micrograph of $\mathrm{Cr}_{3} \mathrm{C}_{2}-\mathrm{NiCr}$ coating 
sity of the D-Gun sprayed coatings is found to be in the range of $0.03-0.29 \%$. The stellite-6 coating exhibits highest hardness of $1098 \mathrm{HV}$, as also reported by Zhang (2003) and Zhao et al (2004). This coating, however, suffered from maximum porosity of $0.29 \%$. The porosity as well as microhardness of the stellite- 6 coating is observed to be highest of the three coatings. The porosity of WC$\mathrm{Co}-\mathrm{Cr}$ coating is found to be lowest of the three coatings, whereas the minimum value of the average microhardness is shown by $\mathrm{Cr}_{3} \mathrm{C}_{2}-\mathrm{NiCr}$ coating. The measured values of porosities of $\mathrm{Cr}_{3} \mathrm{C}_{2}-\mathrm{NiCr}$ and $\mathrm{WC}-\mathrm{Co}-\mathrm{Cr}$ coatings in this investigation are much less as compared to the observations of Sahraoui et al (2003) for HVOF coatings.
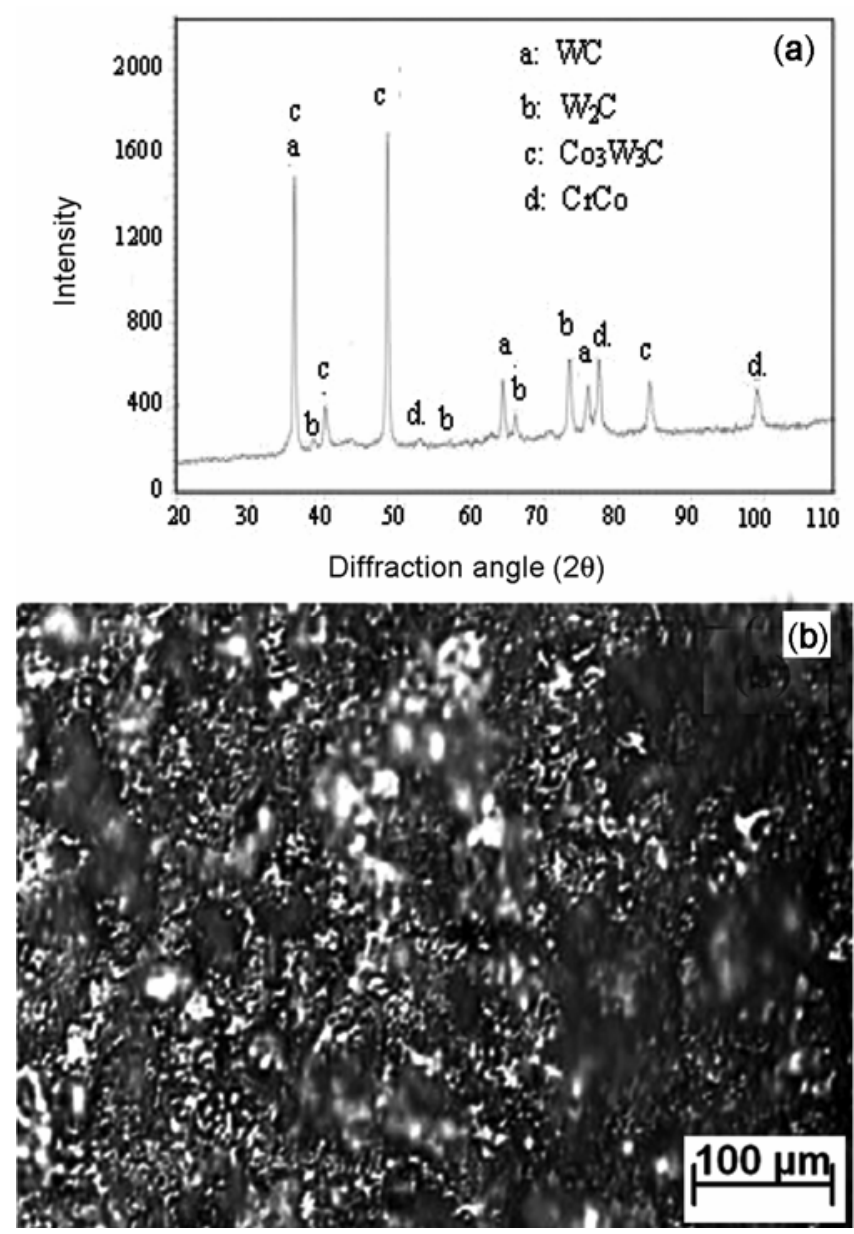

Figure 3. (a) XRD spectra and (b) optical micrograph of WC-Co-Cr coating

Table 4. Porosity and microhardness of coatings.

\begin{tabular}{lcc}
\hline $\begin{array}{l}\text { Coating } \\
\text { material }\end{array}$ & $\begin{array}{c}\text { Average } \\
\text { porosity }(\%)\end{array}$ & $\begin{array}{c}\text { Microhardness } \\
\left(\mathrm{HV}_{0 \cdot 2}\right)\end{array}$ \\
\hline Stellite-6 & $0 \cdot 29$ & 1098 \\
$\mathrm{Cr}_{3} \mathrm{C}_{2}-\mathrm{NiCr}$ & $0 \cdot 10$ & 824 \\
$\mathrm{WC}-\mathrm{Co}-\mathrm{Cr}$ & $0 \cdot 03$ & 990 \\
\hline
\end{tabular}

\subsection{Erosion rate}

Erosion tests were conducted at impingement angles of $30^{\circ}$ and $90^{\circ}$ using silicon carbide particles as erodent. It
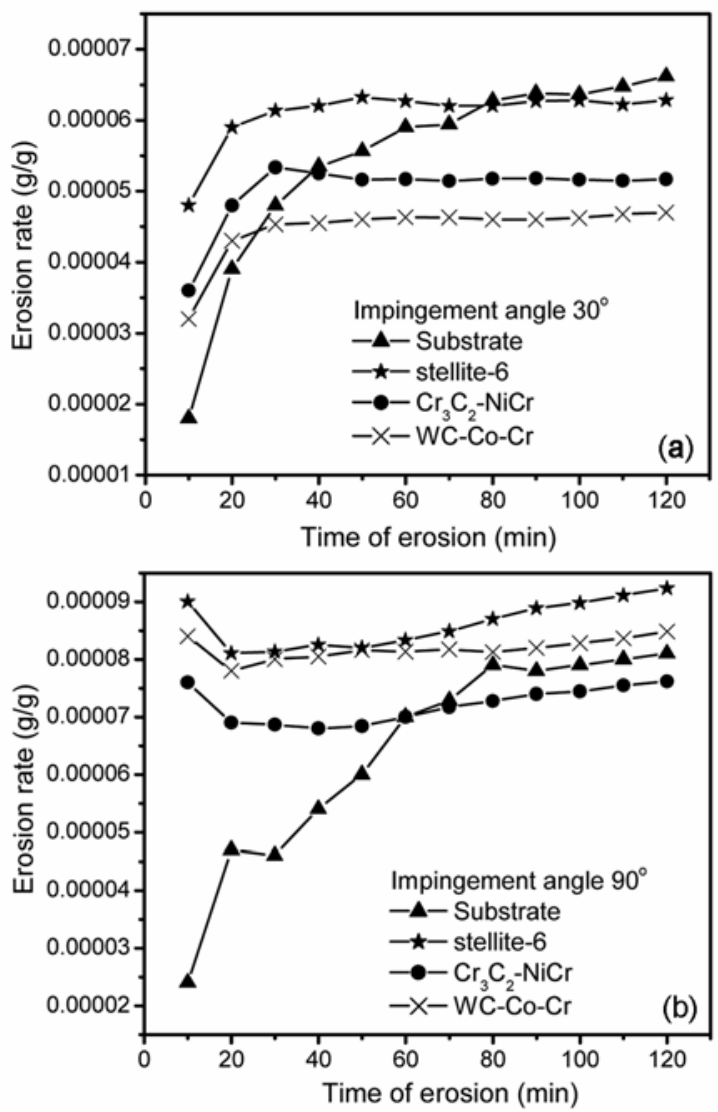

Figure 4. Erosion rate $(\mathrm{g} / \mathrm{g})$ as a function of erosion time for substrate material as well as for various coatings at impingement angles (a) $30^{\circ}$ and (b) $90^{\circ}$.

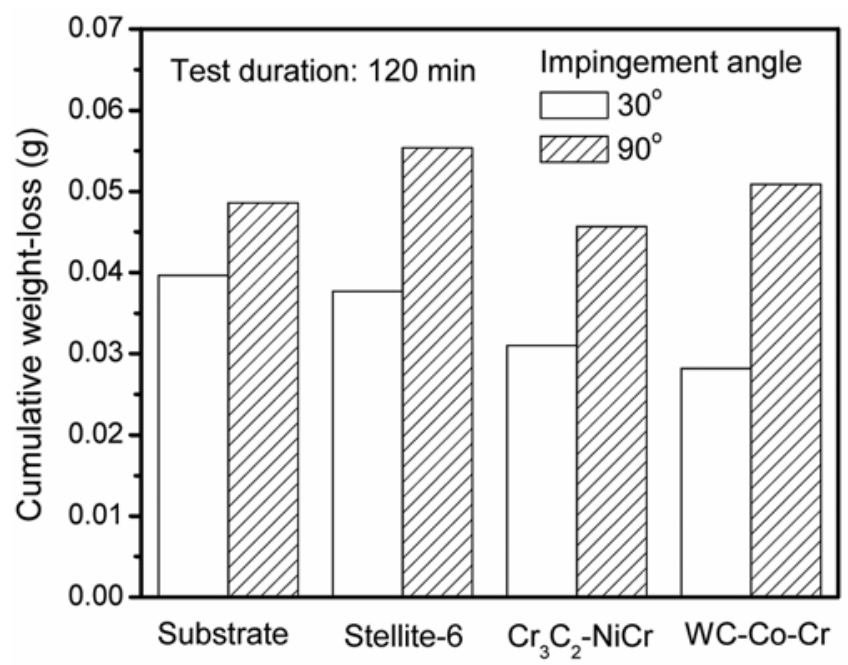

Figure 5. A histogram illustrating cumulative weight loss of substrate (hot rolled 21-4-N steel) and different D-Gun sprayed coatings. 

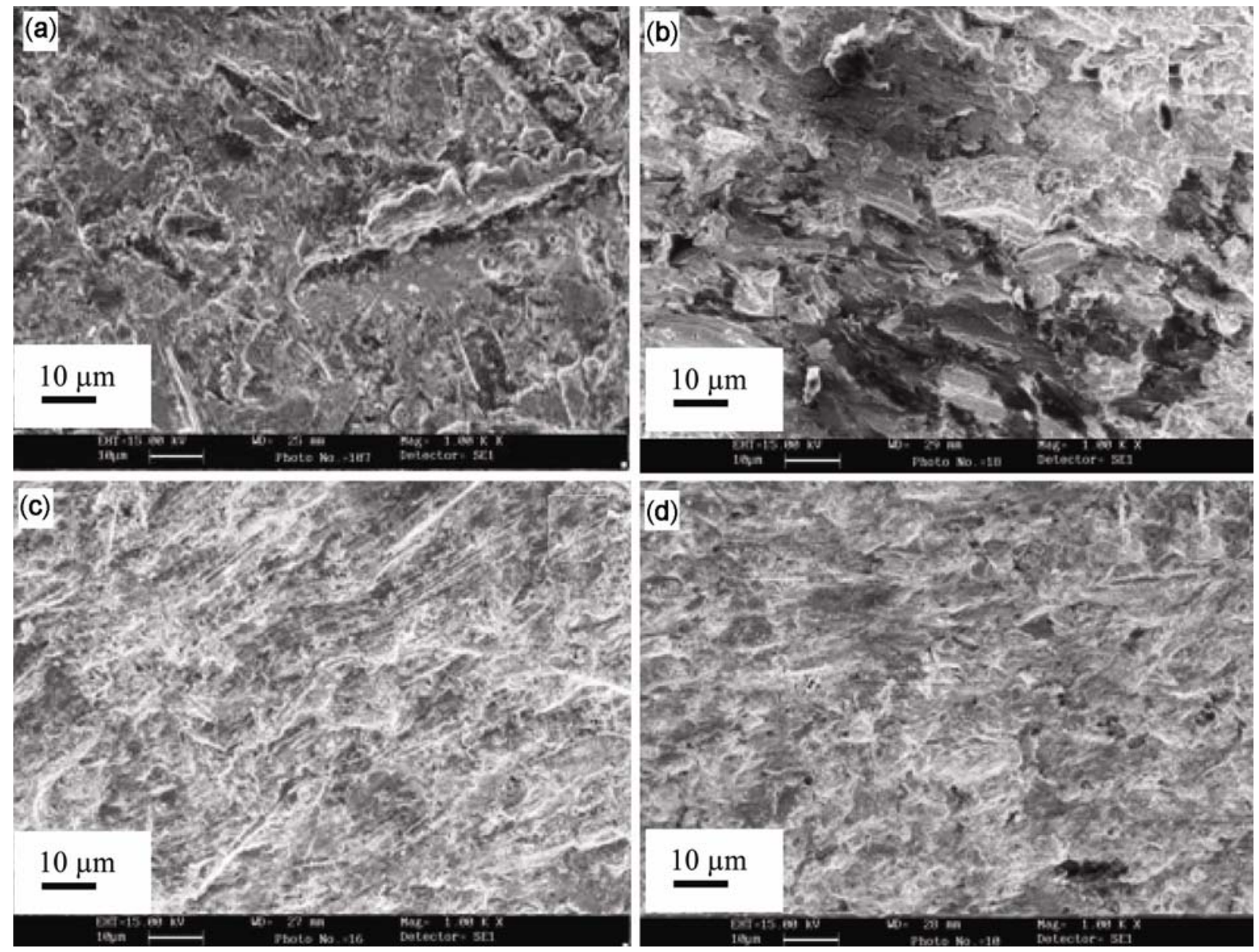

Figure 6. Scanning electron micrographs of eroded surfaces after $120 \mathrm{~min}$ of erosion test at $30^{\circ}$ impingement angle of (a) substrate, (b) stellite-6, (c) $\mathrm{Cr}_{3} \mathrm{C}_{2}-\mathrm{NiCr}$ and (d) $\mathrm{WC}-\mathrm{Co}-\mathrm{Cr}$ coatings.

is seen that at both impingement angles the erosion rate of the substrate material first increases rapidly and then becomes almost constant. The erosion rates of coated specimens at $30^{\circ}$ impingement angle also increases rapidly in the beginning and become almost constant (figure 4a). At $90^{\circ}$ impingement, however, the erosion rates of coatings initially decreases rapidly before attaining steady state values, as seen in figure $4 \mathrm{~b}$. It is also observed that at both $30^{\circ}$ and $90^{\circ}$ impingement angles, the stellite- 6 coating exhibits, in general, the maximum erosion rate. In all cases the $30^{\circ}$ impingement angle yields lower erosion rates in comparison to $90^{\circ}$ impingement. The lowest erosion rate is observed in the $\mathrm{WC}-\mathrm{Co}-\mathrm{Cr}$ coating at $30^{\circ}$ impingement angle.

The erosion damages in terms of cumulative weight loss at the end of erosion test duration of $120 \mathrm{~min}$ are given in bar chart form in figure 5 , which also shows lower erosion damages at $30^{\circ}$ impingement angle. At $30^{\circ}$ impingements angle the erosion loss is primarily due to shear cutting of surface material, whereas at $90^{\circ}$ impingement angle erosion damage is due to strain hardening and embrittlement of target material. The erosion at $90^{\circ}$ impingement angle normally corresponds to erosion of brittle material without any involvement of shear cutting process and thus occurs at high speeds.

The influence of various parameters affecting erosion rate of surface coated materials poses a very complex problem. In general, it is expected that the erosion rate should decrease with increase in hardness and decrease in porosity of the coating (Mishra et al 2006). The erosion rate should also decrease with increased involvement of shear process in the surface cutting of target material. In the presence of all these parameters, it is not possible to quantify the influence of individual parameters on the erosion rate. Hence the results obtained in this study do not exhibit any well defined relationship between hardness, porosity and the erosion rate. For example, as seen in figure 4 , the stellite- 6 coating exhibits maximum erosion damages, even though it possesses maximum hardness. Levy (1988) and Mishra et al (2006) have reported that in plasma sprayed coatings, the greater the porosity of the coating, the easier it is for the erodent particles to knock out pieces from the exposed surface, and greater is the removal rate. The porosity thus has an 

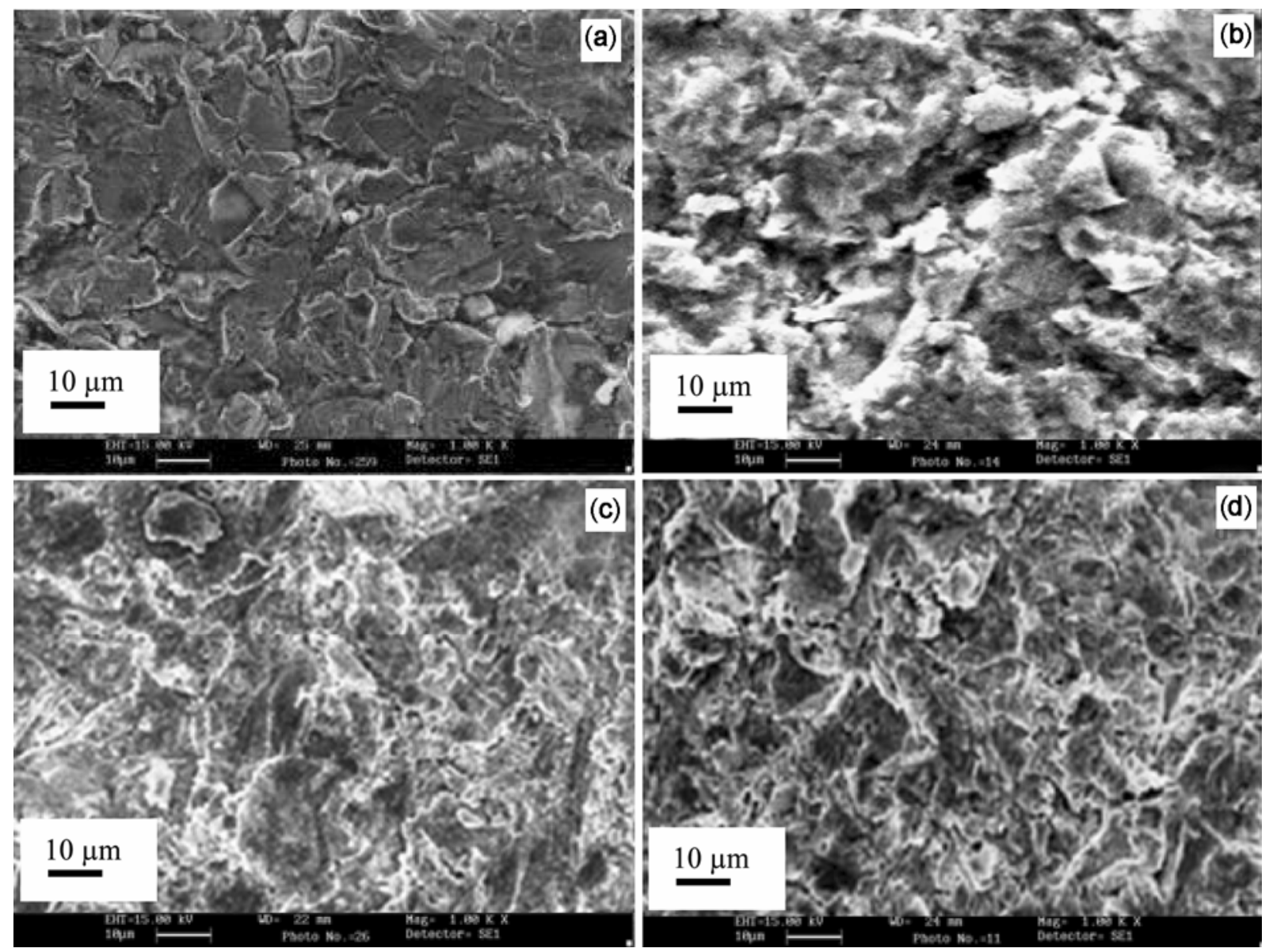

Figure 7. Scanning electron micrographs of eroded surfaces after $120 \mathrm{~min}$ of erosion test at $90^{\circ}$ impingement angle of (a) substrate, (b) stellite-6, (c) $\mathrm{Cr}_{3} \mathrm{C}_{2}-\mathrm{NiCr}$ and (d) $\mathrm{WC}-\mathrm{Co}-\mathrm{Cr}$ coatings.

overwhelming influence on the erosion behaviour of target material.

\subsection{Morphology of eroded surfaces and mechanisms of erosion}

Figures 6 and 7 show the scanning electron micrographs of eroded surfaces of substrate material, stellite- $6, \mathrm{Cr}_{3} \mathrm{C}_{2}-$ $\mathrm{NiCr}$ and $\mathrm{WC}-\mathrm{Co}-\mathrm{Cr}$ coatings at impingement angles of $30^{\circ}$ and $90^{\circ}$, respectively. At $30^{\circ}$ impingement angle the process of erosion involves a shear process. Thus the topography of eroded surfaces in the substrate as well as the coatings indicates presence of ploughs, which are formed due to extrusion of platelets from the impact zone (figure 6). The erosion is characterized by intense localized plastic flow producing lips and ploughs around the crater periphery as suggested by Hearley et al (1999). Wide ploughs are observed in substrate (figure 6a) and stellite-6 coating (figure 6b), which is indicative of high erosion damages. At $30^{\circ}$ impingement angle, cutting due to impinging particle starts in the ductile matrix of stellite- 6 around the large $\mathrm{M}_{23} \mathrm{C}_{6}$ carbide grains leading to acceleration in erosion damages. The $\mathrm{Cr}_{3} \mathrm{C}_{2}-\mathrm{NiCr}$ and
WC-Co- $\mathrm{Cr}$ coatings are continuous and are sufficiently hard to resist cutting due to the impacting erodent particles at $30^{\circ}$ impingement angle. This mechanism of erosion of $\mathrm{Cr}_{3} \mathrm{C}_{2}-\mathrm{NiCr}$ and $\mathrm{WC}-\mathrm{Co}-\mathrm{Cr}$ coatings is supported by the scanning electron micrographs (figures $6 \mathrm{c}$ and $\mathrm{d}$ ). At $90^{\circ}$ impingement angle, the eroded surfaces in all cases are in general free from ploughs (figure 7). Deep craters are instead observed which are created due to dislodging of material by hard hitting erodent particles. The craters as revealed in SEM study are deepest in the stellite6 coating (figure $7 b$ ) in comparison to other coatings. The deep craters observed in the scanning electron micrograph of eroded stellite- 6 coating correspond to the removal of large chunks of carbides due to high level of porosity.

\section{Conclusions}

(I) The stellite- 6 coating on $21-4-\mathrm{N}$ steel substrate exhibits maximum damage due to erosion at $30^{\circ}$ and $90^{\circ}$ impingement angles. Minimum erosion losses are observed in $\mathrm{WC}-\mathrm{Co}-\mathrm{Cr}$ coating at $30^{\circ}$ impingement angle.

(II) The analysis of the influence of various parameters on erosion behaviour poses a complex problem. It is not 
possible to quantify the role of individual parameters like microstructural features, microhardness and porosity in affecting the erosion behaviour of coating. It is, however, observed that the nature and extent of porosity affect to a large extent the erosion rate of coatings. Maximum concentration of porosity is observed in stellite- 6 coating.

(III) The erosion damage at $90^{\circ}$ impingement angle is more severe in comparison to erosion loss at $30^{\circ}$ impingement angle.

(IV) Scanning electron microscopic study reveals that at $30^{\circ}$ impingement angle erosion occurs by a shear process involving formation of lips and ploughs on the target surface. Existence of deep craters in the SEM micrographs at $90^{\circ}$ impingement angle indicates knocking out of chunk of material from the target surface resulting in high rates of erosion.

\section{Acknowledgements}

This investigation has been financially supported by Ministry of Power, Government of India. The steel used was supplied by M/s Star Wire (India) Ltd, Ballabhgarh (India).

\section{References}

Barbezat G, Nicoll A and Sickinger A 1993 Wear 162-164 529

Chauhan A K, Goel D B and Prakash S 2009 J. Alloys Compd 459-464 467

Fagoaga I, Viviente J L and Gavin P 1998 J. Thin Solid Films 317259
Guo D Z, Li F L, Wang J Y and Sun J S 1995 Surf. Coat. Technol. 7373

Hearley J A, Little J A and Sturgeon A J 1999 Wear 233-235 328

Herman H and Sampath S 1996 in Metallurgical and ceramic protective coatings (ed.) K H Stern (London, UK: Chapman and Hall) p. 261

Ji G C, Li C J, Wang Y Y and Li W Y 2006 Surf. Coat. Technol. 2006749

Kosel T H 1992 ASM Handbook 18199

Levy A V 1988 Surf. Coat. Technol. 36387

Mishra S B, Prakash S and Chandra K 2006 Wear 260422

Murthy J K N, Rao D S and Venkataraman B 2001 Wear 249 592

Sahraoui T, Fenineche N, Montavon G and Coddet C 2003 Mater. Design 24309

Semenov S Y and Cetegen B M 2002 Mater. Sci. Eng. A335 67

Shipway P H and Hutchings I M 1994 Wear 174169

Shipway P H and Hutchings I M 1995 Surf. Coat. Technol. 711

Sidhu H S, Sidhu B S and Prakash S 2007 Surf. Coat. Technol. 202232

Singh H, Puri D and Prakash S 2005 Anti-Corros. Meth. Mater. 5284

Takeda K, Ito M, Takeuchi S, Sudo K, Koga M and Kazama K 1993 ISIJ Int. 33976

Wang B and Lee S W 2000 Wear 23983

Wang J, Zhang L, Sun B and Zhou Y 2000 Surf. Coat. Technol. 13069

Wang Y 1993 Wear 16169

Wood R J K and Wheeler D W 1999 Wear 22095

Zhang K 2003 Wear 255545

Zhang P, Jiang J, Ma A, Wang Z, Wu Y and Lin P 2007 Adv. Mater. Res. 15-17 199

Zhao L, Zwick J and Lugscheider E 2004 Surf. Coat. Technol. 18272 